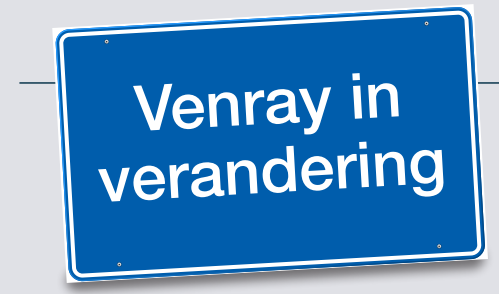

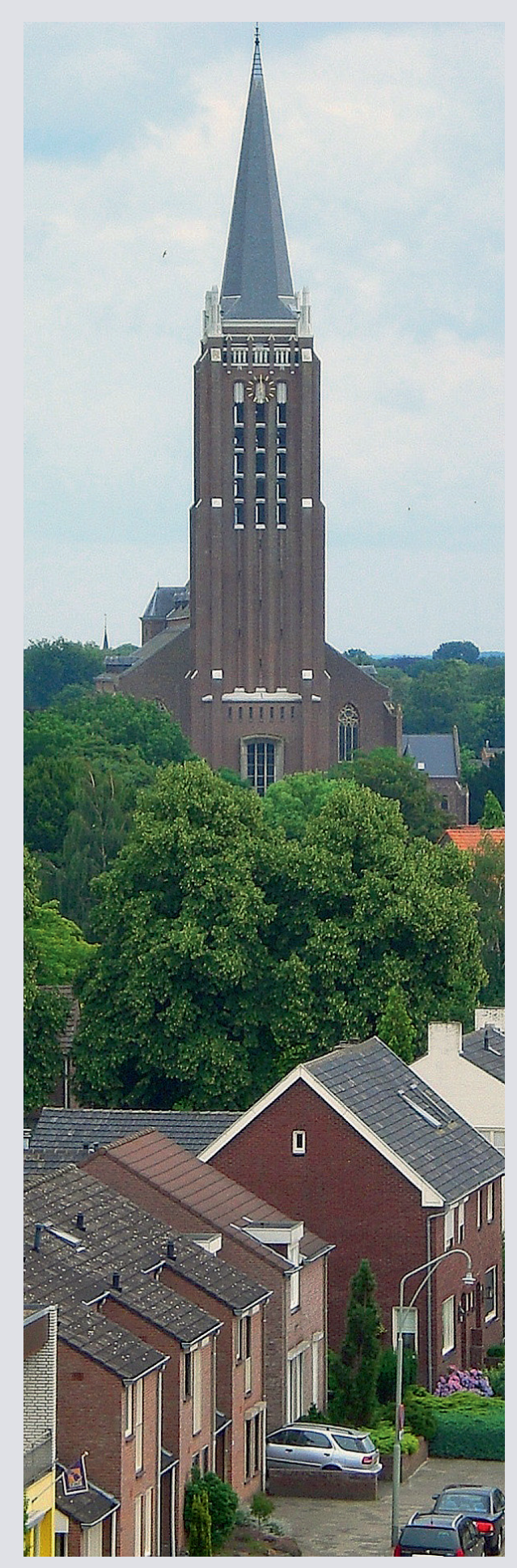

Dik 400 gemeenten hebben hun handen vol aan de transities in het sociaal domein. Stan Verhaag volgt de ontwikkelingen in Venray op de voet.

\title{
Vergaderen in Leunen
}

\author{
Moeten we ons abonnement op de Vereniging Kleine \\ Kernen Limburg opzeggen of verlengen? Over die \\ vraag vergadert de dorpsraad in Leunen. Venray- \\ watcher Stan Verhaag is aandachtig toehoorder.
}

$\mathrm{n}$ Limburg bestaat een vereniging

die zich inzet voor de kleine kernen.

In mijn leven komt die vereniging elk jaar wel één of twee keer voorbij. Als ik een bewonersbijeenkomst bijwoon. Of als het ergens gaat over leefbaarheid. Maar hoe heet die club ook alweer? Limburgse Vereniging van Kleine Kernen? LVKK? Vereniging Van Limburgse Kleine Kernen? VVLKK? Ik blijk niet de enige te zijn die worstelt met de Limburgse Kleine Kernen Vereniging (LKKV), of hoe hij ook heten mag. Op een zomerse maandagavond in augustus bezoek ik de dorpsraadvergadering in Leunen, een van de kernen van het mooie Venray. En daar komt ie weer voorbij. Agendapunt 8: Abonnement VKKL. Deze dorpsraad blijkt een abonnement te hebben op de VKKL, de Vereniging Kleine Kernen Limburg. Zo heet hij dus. En je kunt erop geabonneerd zijn. Maar er is slecht nieuws: tijdens de vorige vergadering heeft de Leunse dorpsraad juist besloten het abonnement op te zeggen.

'Want we deden er eigenlijk niks mee', licht de voorzitter toe. Waarom de VKKL dan toch weer op de agenda staat? Een van de dorpsraadsleden vertelt: 'Naar aanleiding van onze opzegging is de VKKL in Leunen geweest en hebben we een gesprek gehad.' Dan haalt hij een grote envelop tevoorschijn. 'En gisteravond heb ik per koerier nog folders van ze gekregen.' Gekscherend: 'Ik heb ze nog niet allemáál gelezen, hoor!' Het materiaal gaat rond. Op een uitklapposter staat: 'De VKKL helpt, motiveert en inspireert Limburgers die nadenken over leefbaar- heid.' Een folder heeft als kop: 'Ik wil zo lang mogelijk in mijn eigen buurt blijven wonen!' ('Een terechte wens, maar hoe gaat $\mathrm{u}$ dat realiseren?') En er is een folder over zorginitiatieven. ('Dat is zijn bewonersinitiatieven op het gebied van zorg en welzijn. Ze ontstaan steeds meer door de vergrijzing, nieuw overheidsbeleid en een mondigere samenleving.') 'Ik heb begrepen dat ze niet alleen zelf een bepaald aanbod hebben', zegt de man die het gesprek met de VKKL voerde, 'maar ze spelen ook in op de vraag die jij stelt.' $\mathrm{Al}$ snel begint het voorlichtings- c.q. charmeoffensief van de VKKL vruchten af te werpen. Vertelt het ene dorpsraadslid dat het plaatselijke tankstation gaat stoppen met de verkoop van levensmiddelen en dat vooral de senioren dat zonde vinden. ('Voor hen is het een uitje.')Zegt de ander: 'Misschien weet de VKKL hoe je in een kleine kern een buurtsuper kunt beginnen.' Vertelt de voorzitter dat haar werkgroep binnenkort start met het dorpsontwikkelingsplan 2030. Zegt ze erachteraan: 'Misschien kan de VKKL daar wel bij helpen.' Er ontstaat zowaar iets van VKKL-enthousiasme. Zegt een ander, bladerend in een folder: 'Ze helpen ook als je van je kerk een gemeenschapshuis wilt maken. Dat lijkt mij wel wat.' Het kan verkeren. De voorgenomen opzegging is uit het collectieve geheugen van de dorpsraad verdwenen. De VKKL leeft weer in Leunen. 'Misschien kunnen we ze een jaar lang af en toe een vraag stellen', oppert iemand. 'Kijken hoe ze reageren. Voor die vijftien of twintig euro abonnementskosten hoeven we het niet te laten.' - 